\title{
Perceived Social Support as Predictor of Suicide Ideation in Gunung Kidul High School Students
}

\author{
Safira Naila ${ }^{1 *}$ and Bagus Takwin ${ }^{2}$ \\ ${ }^{1,2}$ Faculty of Psychology, University of Indonesia, Depok, Indonesia \\ Email: safiranailaa@gmail.com
}

\begin{abstract}
This study aims to examine the role of social support as a predictor of suicide ideation in Gunung Kidul, a resident with the highest suicide rate in Indonesian high school students. Previous research shows links between perceived social support and suicide ideation, but little is known if the relation applies in the context of Gunung Kidul. Perceived social support is measured with Multidimensional Scale of Perceived Social Support (MSPSS) and suicide ideation is measured with The Scale of Suicide Ideation (SSI). This research involves 260 high school students in Wonosari and Semanu, Gunung Kidul. Regression analysis shows that perceived social support contribute to the decrease of suicide $(\mathrm{p}<0.01)$, with $\mathrm{R}^{2}$ value $11.3 \%$ dan $\beta$ value -0.276 . This shows that perceived social support is a significant predictor to decrease suicide ideation. This result can be a good consideration for intervention about suicide ideation in Gunung Kidul.
\end{abstract}

Keywords: Adolescents; Gunung Kidul; High School Students; Perceived Social Support; Suicide Ideation

\section{Introduction}

WHO (World Health Organization) reported that Indonesia has 3.6 suicide cases per 100.000 citizens (WHO, 2017). Among all regions in Indonesia, Gunung Kidul, a regency in Yogyakarta province, has the highest prevalence of suicide. with 9 cases per 100.000 citizens, which is three times higher than the rates in whole Indonesia. The prevalence is also higher than Jakarta, the capital city of Indonesia, which is 1.2 cases per 100.000 citizens (Rozaki, 2012).

In the previous years, persons who lost their lives of suicide are elderly and adult. However, recently the group age shifted to adolescents (Rochmawati, 2009; Kiki, 2011; Rozaki, 2012; Suryani, 2016). For example, in 2011, there were 28 cases of teenagers and children with the youngest perpetrator a 10year-old child. The motives come from various factors such as economic difficulties (Suryani, 2016), chronic stress (Kiki, 2011), and many other unknown motives.

The local government find these suicidal ideation phenomena as problematic because the factors are still unpredictable (Priherdityo, 2016). People who attempted suicide attempt, committed suicide, and have suicide ideation are not well recorded, so the causes cannot be determined yet. Whereas, those who commit suicide usually have the ideation first then followed by a suicide attempt that ends in killing oneself (Whisman \& McCoy, 1997; Wenzel, Brown, \& Beck, 2009).

Some research towards the perpetrator's family members showed that some possible causes of suicide are the lack of social support, hopelessness, hallucination experience, rationalization of suicide as solutions for their problems, overly rigid way of thinking, impulsivity, and depression (Rochmawati, 2009). Other factors include poverty, chronic illness, gender issue where males face high social pressure from society, and maladaptive coping behavior (Fahrudin, 2012). In particular, according to an interview to 10 teenage and children perpetrators' closest family member, lack of social support is assumed to be one of the important factors that cause teenager and child to commit suicide (Rochmawati, 2009). This is supported by an interview conducted by researchers in this study to few high school students there. For them, support from parents and friends is the most important thing in their lives. When imagining life without their support, they admit that they will feel stress.

The interview result above can be explained by Erikson's psychosocial theory. Adolescence (11-20 years old) is the time when social support is very important for someone (Papalia \& Martorell, 2014). Social support (including social connection and network) is the main resource and also the main 
developmental task for an adolescent. In this stage, if someone succeeds to find self-identity, someone will reach fidelity virtue, where someone will own loyalty, trust, and sense of belonging] towards people around them. To reach that virtue, someone have to find their identity by socializing with new friends; while still hold their family's values (Barrera, 2000). Otherwise, if someone failed to reach that virtue, they will not have a sense of self (not knowing oneself), feel insecure, and cannot plan their future well. Also, someone will not have enough emotion and psychosocial competence to go to the next stage, adulthood (Papalia \& Martorell, 2014).

Generally, social support can decrease negative effect of the stressor on someone's life (Barrera, 2000). Social support can help change the meaning of life stressor to be more positive, change the situations, and change reactions toward stressor (Zimet et al., 1988; Barrera, 2000). Social support can also enhance self-esteem and make someone feel that they can control situations around them (Pearlin, Liebermen, Menaghan, \& Mullan, 1981; Barrera, 2000). Also, it can lower depression and anxiety as part of reactions toward stressor (Barrera, 2000).

The actual amount of social support (quantitatively measured) cannot always predict psychological symptoms experienced by someone (Barrera, 1986; Barrera, 2000). Social support will be beneficial only if it is perceived as needed and sufficient, while the unneeded support will be perceived as a burden (Barrera, 1986; Barrera, 2000). Therefore, social support that is perceived subjectively (satisfaction about social support being received by someone) can more accurately predict physical and psychological symptoms that are experienced (Zimet et al., 1988; Barrera, 2000).

Some studies show that perceived social support almost always decrease the possibility of depressive symptoms to emerge (Thoits, 1986; Rigby \& Slee, 1999; Harris \& Molock, 1999; Khazaeipour, Hajiaghababaei, Mirminachi, Vaccaro, \& RahimiMovaghar, 2017). Meanwhile, depression correlates positively with suicide ideation and can predict suicide ideation. Depression symptoms, as the main predictor of suicide ideation, can be reduced with available and sufficient perceived social support (Beck, Kovacs, \& Weissman, 1979; Barrera, 2000; Brown, Beck, Steer, \& Grisham, 2000; Cheung, Law, Chan, Liu, \& Yip, 2006).
According to some research conducted by Kimbrough et al. (1996), Ponizovsky and Ritsner (1999), Harris \& Molock (2000), Lieberman et al. (2005), and Cho \& Haslam (2010), perceived social support can predict suicide ideation. This means that high perceived social support can decrease the possibility of suicide ideation to emerge. This is consistent with stress prevention model from Barrera (2000). According to Barrera, if someone perceived their social support as available and sufficient, that will protect them from the negative effect of life stressor. That means, if someone has good perceived social support, this will make someone stronger before experiencing stress itself.

Previous research regarding Gunung Kidul were conducted to family members and close friends of the perpetrators, and no previous research has covered about the suicide perpetrators or suicide ideation. The current researchers see the need to conduct a study about suicide ideation to better predict future suicidal behavior. This research is conducted to high school students in Wonosari and Semanu district, in Gunung Kidul. High school students are chosen because they are in the developmental stage when social support is very important to them. They also begin to receive social pressure about their future plan and being pressured to act like an adult.

\section{Methods}

Sample. Participants in this research are 260 high school students in Wonosari and Semanu, two subdistricts in Gunung Kidul. The high school students must be between 15 to 19 years old and must be a resident of Gunung Kidul regency, because suicide rate in Gunung Kidul is the highest. With these requirements, 10 participants are eliminated and the rest of 250 participants are being analyzed.

The researchers used stratified sampling (Gravetter $\&$ Forzano, 2011) to determine which classes will be the target of this research. So, in every school, there are three classes being chosen and represented every grade in Gunung Kidul high school; one from the $1^{\text {st }}$ grade, one from the $2^{\text {nd }}$ grade, and one from the $3^{\text {rd }}$ grade. We ask the teacher on duty to choose the available classes.

Research Design. The researchers use the quantitative design to see the correlation between 2 variables (Kumar, 2011). The aim is to determine if variable 1 can predict variable 2 , and also control variable 3 . There are 3 variables in this research; 
perceived social support, suicide ideation, and social desirability (controlled).

\section{Instrument and Measurement}

Multidimensional Scale of Perceived Social Support (MSPSS). This instrument is used to measure participants' perception about social support received. This instrument consists of 12 items, used a 4-point scale consists of 4 choices, 1 for strongly disagree, 2 for disagree, 3 for agree, and 4 for strongly agree. The scores are ranging from $4-48$ points, with reliability coefficient 0.755 . The score below 25 represents low perceived social support, score from 25 to 36 represents moderate perceived social support, and score above 36 represents high perceived social support (Zimet, Dahlem, Zimet, \& Farley, 1988). This instrument was adapted to Indonesian by Trifilia (2013).

The Scale of Suicide Ideation (SSI). This instrument is used to scan people that have suicide ideation. It measures intensity, the pervasiveness of the ideation. It consists of 18 items with 3 choices in every item, scores ranging from $0-36$. The choices are different for every item, but represent the same notion; 0 for no ideation, 1 for moderate ideation, and 2 for severe ideation. Score 0 will be for participants who don't have suicide ideation at all, meanwhile, score 36 will be for participants who have very intense suicide ideation. The score above 1 shows that participants have suicide ideation (Beck, Kovacs, Weissman, 1979; Wenzel, Brown, Beck, 2009). This instrument is already adapted in Indonesia by Denisa (2013) and has 0.837 for reliability coefficient.

Marlow-Crowne Social Desirability Scale. This instrument is used to measure how much participants want to be seen as ideal by the society. It also means to measure if the participant is responding honestly to the instruments (Marlow \& Crowne, 1960). This instrument is already adapted to Indonesian culture.

Procedure. In every school, the researchers enter every classroom that is chosen and brief the students about this research. What this is for and what this is about. Then, researchers give choice to students if they want to participate or not. The students that didn't want to participate are allowed to wait outside the classroom during data collection. If they agree to participate, they must fill every question and personal information provided. Every instrument is being checked to ensure that they fill every question and personal information. Their identity is kept secret and only the name initial is written. One ballpoint is given as a reward to every student that participates in this research.

\section{Results}

Participants in this study are mostly students who live in the forest part of Gunung Kidul $(n=143,57.2$ $\%$ ) followed by those who live in the residential area $(\mathrm{n}=82$ or $32.8 \%)$. Most of the participants are female $(n=164$ or $65.6 \%)$. There are 6 students that are not the citizen of Gunung Kidul, and 4 students who did not complete their personal information. So those students $(n=10)$ are excluded from this study.

From the questionnaire results, there are $n=93$ students that have suicide ideation $(37.8 \%)$ and $\mathrm{n}=$ 157 students do not have suicide ideation at all (62.8 $\%)$. Meanwhile, those who have suicide ideation have scores ranging from 1-33 (from maximum score 36). Male students $(\bar{x}=1.60)$ have significantly higher suicide ideation than female $(\bar{x}=$ 0.67). Meanwhile, female $(\bar{x}=38.80)$ have significantly higher perceived social support than male students $(\bar{x}=37.44)$.

The result indicated that perceived social support significantly predict suicide ideation $\left(R^{2}=.113, F\right.$ $(250)=21.12, p<.01)$, and also $11.3 \%$ variance of suicide ideation could be explained by perceived social support. Furthermore, if we look at the source of perceived social support one by one, every increase in source of friend can predict lower decrease in suicide ideation significantly $(B=-0.251$ and sig. $=0.004)$. The $\beta$ of source of friend is higher than $\beta$ of total perceived social support.

Table 1.

Sample Characteristics

\begin{tabular}{|c|c|c|c|}
\hline $\begin{array}{c}\text { Demographic } \\
\text { Aspect }\end{array}$ & Data & Frequency & $\begin{array}{c}\text { Percentage } \\
(\%)\end{array}$ \\
\hline \multirow[t]{2}{*}{ Gender } & Male & 86 & 34.4 \\
\hline & Female & 164 & 65.6 \\
\hline \multirow[t]{5}{*}{ Age } & 15 & 27 & 10.8 \\
\hline & 16 & 93 & 37.2 \\
\hline & 17 & 92 & 36.8 \\
\hline & 18 & 35 & 14.0 \\
\hline & 19 & 3 & 1.2 \\
\hline \multirow{3}{*}{$\begin{array}{c}\text { Parents' } \\
\text { Monthly Wage }\end{array}$} & Under & & \\
\hline & $\begin{array}{l}\text { UMK } \\
\text { Above }\end{array}$ & 129 & 51.6 \\
\hline & UMK & 121 & 48.4 \\
\hline \multirow[t]{3}{*}{ Living Area } & Beach & 25 & 10 \\
\hline & Capital city & 82 & 32.8 \\
\hline & Forest & 143 & 57.2 \\
\hline
\end{tabular}


Table 2

F-Table of perceived social support

\begin{tabular}{ccccc}
\hline \multirow{2}{*}{ Predictor } & \multicolumn{4}{c}{ Outcome: suicide ideation } \\
\cline { 2 - 5 } & $\boldsymbol{F}$ & $\boldsymbol{R}^{\mathbf{2}}$ & $\boldsymbol{\beta}$ & Sig. \\
\hline $\begin{array}{c}\text { Perceived Social } \\
\text { Support }\end{array}$ & 21.12 & .0113 & -.276 & .000 \\
\hline
\end{tabular}

Table 3

Source of support

\begin{tabular}{lcc}
\hline Source of Support & B & Sig. \\
\hline Family & -0.146 & 0.139 \\
Friend & -0.251 & 0.004 \\
Significant Other & -0.123 & 0.125 \\
\hline
\end{tabular}

\section{Discussion \& Conclusion}

Discussion. The present study found that perceived social support can predict suicide ideation significantly. This result is consistent with the previous researches (Kimbrough et al., 1996; Ponizovsky \& Ritsner, 1999; Harris \& Molock, 2000; Lieberman et al., 2005; Cho \& Haslam, 2010). This might be because social support can function as a buffer from stress (Thoits, 1986; Barrera, 2000) to change the meaning of stress (Zimet et al., 1988; Barrera, 2000), also can make someone feel in control about their environments and situation.

For social support to have that impact, it must be perceived as sufficient and needed by someone. That explains why someone who has high perceived social support can face stressful event better and more successfully (Barrera, 1986; Barrera, 2000). Meanwhile, those who have low perceived social support feel like they cannot solve all their problems and it will make them more likely have depressive symptoms (Kimbrough et.al., 1996; Ponizovsky \& Ritsner, 1999; Harris \& Molock, 2000; Lieberman et al., 2005; Cho \& Haslam, 2010). Apparently, at some point, they will have suicide ideation because depression is the biggest predictor of suicide ideation (Beck, Kovacs, \& Weissman, 1979; Brown, Beck, Steer, \& Grisham, 2000; Cheung, Law, Chan, Liu, \& Yip, 2006).

This study also shows that friend as a social support source is the only source that can predict suicide ideation significantly $(\beta=-0.251$ and sig. $=0.004)$ and also has bigger $\beta$ compared to total perceived social support. This is consistent with research by Cheng and Chan (2004) to teenagers that found perceived friend support is higher than perceived family support.

From this study, we can also see that $11.3 \%$ of suicide ideation variance can be explained by perceived social support. There are still $88.7 \%$ variances that are not studied yet and can be explained by many other factors. Those factors could be a situational factor such as economic condition. Or genetic factors such as personality type, or state factors such as chronic illness.

Comparing the two variables and demographic data, only gender aspect has been found to differ significantly between two variables. It has also been found that female participants have significantly higher perceived social support than male participants. It is consistent with research by Shumaker and Hill (1991) that females give and need more social support than males. Perceived social support also has been found to differ significantly in participants, in terms of the area they lived in.

Males also appear to have significantly higher suicide ideation than females. This is not consistent with research by Weissman et al. (1999) that shows female have higher suicide ideation than males, even though it is not significant.

This research has few limitations; not proportionate data collecting in the gender aspect. Also, researchers have yet to involve participants from SMK and MA for the high school students. Also, for the economic situation (parents' monthly wage), researchers do not put the appropriate criterion for differentiating the participants.

For the future research, we suggest that the researcher can collect proportionate participants in terms of gender. The researcher can use proportionate random sampling technic so both female and male participants will be more proportional and therefore could be more representative in the population (Gravetter \& Forzano, 2011). Also, the researcher can use UMK (Upah Minimum Kabupaten) or minimum wage of parents as a criterion to see participants' economic situation. This will be more accurate to see their standard of living. The researchers also need to involve high school students from Karangmojo, because according to local police research database, Karangmojo is the area with the $2^{\text {nd }}$ highest suicide rate in Gunung Kidul. The researchers also need to involve high school students from SMK and MA to 
get a full picture of suicide ideation in a different high school type of background.

Another further analysis: what do they define as friends? Is it just friends, or very close one, or peer groups?

Although this research has some limitations, there are also a few suggestions that can be applied. For high school students, it is better to always ask other students how are they doing, and offer help when it is needed. At the same time, always ask for help from people around them if needed (if the students themselves have problems).

For the teachers, it is suggested to increase social activities within the students, for example, group papers, group outing, and outside class activities. Teachers have to be more sensitive to their students too, if students appear to be gloomy and alone, teachers have to get close to them until they open themselves. Also, more importantly, teachers need to be trained to improve their intervention skill, such as counseling, conducting motivational interviewing, etc. It is important so that they can give proper group/intervention training for the students as well as fellow teachers. There is also a suggestion for police and psychiatrist to consider perceived social support as a suicide ideation intervention material for high school students.

Conclusions. According to data analysis, we can conclude that perceived social support can be a predictor of suicide ideation on high school students in Gunung Kidul with negative $\beta$ value. It means that in every increase of perceived social support score, there will be a decrease of suicide ideation score. This is consistent with research hypothesis that perceived social support can predict suicide ideation on high school students in Gunung Kidul. The biggest perceived social support source for high school students in Gunung Kidul is friend. Friends mentioned here are those that one perceived as a close friend, how close they are in reality does not really matter.

\section{References}

Barrera, M. (1986). Distinctions between social support concepts, measures, and models. American Journal of Community Psychology, 14(4), 413-445. http://dx.doi.org/10.1007/bf00922627

Barrera, M. (2000). Social Support Research in Community Psychology. In Handbook of Community Psychology (pp. 215-245). New York: Kluwer Academic/Plenum Publishers.
Beck, A., Kovacs, M., \& Weissman, A. (1979). Assessment of suicidal intention: The Scale for Suicide Ideation. Journal of Consulting And Clinical Psychology, 47(2), 343-352. http://dx.doi.org/10.1037/0022-006x.47.2.343

Brown, G. K., Beck, A.T., Steer, R. A., \& Grisham, J. R. (2000). Risk factors for suicide in psychiatric outpatients: A 20-year prospective study. Journal of Consulting and Clinical Psychology. 68, 371-377.

Cheung, Law, C., Chan, B., Liu, \& Yip, P. (2006). Suicidal ideation and suicidal attempts in a population-based study of Chinese people: Risk attributable to hopelessness, depression, and social factors. Journal of Affective Disorders, 90(2-3), http://dx.doi.org/10.1016/j.jad.2005.11.018 193-199.

Cheng, S., \& Chan, A. (2004). The multidimensional scale of perceived social support: dimensionality and age and gender differences in adolescents. Personality and Individual Differences, 37(7), 1359-1369. http://dx.doi.org/10.1016/j.paid.2004.01.006

Cho, Y., \& Haslam, N. (2009). Suicidal Ideation and Distress Among Immigrant Adolescents: The Role of Acculturation, Life Stress, and Social Support. Journal of Youth And Adolescence, 39(4), 370-379. http://dx.doi.org/10.1007/s10964-009-9415-y

Denisa, S.H. (2013). Relationship between Hopelessness and Suicide Ideation on People with Drug Abuse in Social Homes Pamardi Putra (Undergraduate). Universitas Katolik Soegijapranata

Fahrudin, A. (2012). Suicide Phenomenon in Gunung Kidul: Trace Notes from the Field from Lapangan. Informasi, 17(1). Retrieved from https://www.researchgate.net/publication/308983747_Fen omena_Bunuh_Diri_di_Gunung_Kidul_Catatan_Tersisa_ dari_Lapangan_Suicide_phenomena_in_Gunung_Kidul_ Remaining_record_from_the_field

Gravetter, F., \& Forzano, L. (2011). Research methods for the behavioral sciences (1st ed.). Belmont, Calif.: Wadsworth.

Harris, T.L. \& Molock, S.D. (2000). A Longitudinal Investigation of Depression, Hopelessness, Social Support, and Major and Minor Life Events and Their Relation to Suicidal Ideation in Adolescents. Suicide and Life-Threatening Behavior. 28(4).

Kiki, D.S. (26 December 2011). Because of Stress, Teenagers Commit Suicide. Joglosemar, Retrieved from http://edisicetak.joglosemar.co/berita/stres-remaja-bunuhdiri-63716.html

Kimbrough, R., Molock, S., \& Walton, K. (1996). Perception of Social Support, Acculturation, Depression, and Suicidal Ideation Among African American College Students at Predominantly Black and Predominantly White Universities. The Journal Of Negro Education, 65(3), 295. http://dx.doi.org/10.2307/2967346

Kumar, R. (2011). Research methodology: A Step-By-Step Guide for Beginners (3rd ed.). London: Sage Publications Ltd.

Lieberman, Z., Solomon, Z., \& Ginzburg, K. (2005). Suicidal Ideation Among Young Adults: Effects of Perceived Social Support, Self-Esteem, and Adjustment. Journal Of Loss And Trauma, 10(2), 163-181. http://dx.doi.org/10.1080/15325020590908867 
Papalia, D. \& Martorell, R. (2014). Experience human development (13th ed.). New York: McGraw-Hill.

Pearlin, L.I., Menaghan, E.G., Lieberman M.A., \& Mullan, J.T. (1981). The Stress Process. Journal of Health and Social Behavior, 22(4), retrieved from http://www.jstor.org/stable/2136676

Ponizovsky, A.M. \& Ritsner, M.S. (1999). Suicide Ideation among Recent Immigrants to Israel from the Soviet Union: An Epidemiological Survey of Prevalence and Risk Factors. Suicide and Life-Threatening Behavior. 29(4).

Priherdityo, E. (23 Juni 2016). Suicide Incidents Doesn't Seen as Serious Incidents in Indonesia. CNN Indonesia, Retrieved from http://www.cnnindonesia.com/gayahidup/20160623125239-255-140375/kejadian-bunuh-diritak-dianggap-serius-di-indonesia/

Rigby, K. \& Slee, P. (1999). Suicidal Ideation among Adolescent School Children, Involvement in BullyVictim Problems, and Perceived Social Support. Suicide and Life-Threatening Behavior. 29(2).

Rochmawati, I. (2009). Nglalu: Seeing Suicide Phenomenon with Conscience (1st ed.). Yogyakarta: Jejak Kata Kita.

Rozaki, A. (2017). Suicide Among Children and Teenagers in Indonesia. Kyoto Review of Southeast Asia. Retrieved 19 April 2017, from https://kyotoreview.org/bahasaindonesia/bunuh-diri-di-kalangan-anak-dan-remajaindonesia/

Shumaker, S., \& Hill, D. (1991). Gender differences in social support and physical health. Health Psychology, 10(2), 102-111. http://dx.doi.org/10.1037//0278-6133.10.2.102
Suryani, B. (2016). Squeezed by Economical Problems, 19 Year Old Teenager Choose to Hang Herself. Harian Jogja, Retrieved on April 15, 2017, from http://www.harianjogja.com/baca/2016/12/12/bunuh-dirigunungkidul-terhimpin-masalah-ekonomi-remaja-19tahun-pilih-gantung-diri-775996

Thoits, P.A. (1986). Social Support as Coping Assistance. Journal of Consulting and Clinical Psychology.. 54(4).

Trifilia, E. (2013). Relationship Between Perceived Social Support and Self-Esteem among Undergraduate Psychology. (Undergraduate). Universitas Indonesia.

Weissman, M., Bland, R., Canino, G., Greenwald, S., Hwu, H., \& Joyce, P. et al. (1999). Prevalence of suicide ideation and suicide attempts in nine countries. Psychological Medicine, (29), 9-17.

Wenzel, A., Brown, G., \& Beck, A. (2009). Cognitive Therapy for Suicidal Patients: Scientific and Clinical Applications (1st ed., pp. 15-30). Washington, DC: American Psychological Association.

WHO. (2015). Age-Standardized Suicide Rates. World Health Organization. Diakses pada 15 April 2017 from http://Gamapserver.who.int/gho/interactive_charts/mental _health/sucide_rates/atlas/html

Zimet, G.D., Dahlem, N.W., Zimet, S.G., \& Farley, G.K. (1988). The Multidimensional Scale of Perceived Social Support. Journal of Personality Assessment. 52(1). 